\title{
The composition of northeast pacific fishes in a fish tank examined by eDNA metabarcoding
}

\author{
Sergei V. Turanov ${ }^{1,2 *}$, Olesia A. Rutenko ${ }^{1,3}$ \\ ${ }^{1}$ Laboratory of Molecular Systematic, A.V. Zhirmunsky National Scientific Center of Marine \\ Biology, Far Eastern Branch, Russian Academy of Sciences, 690041 Vladivostok, Russia \\ ${ }^{2}$ Chair of Water Biological Resources and Aquaculture, Far Eastern State Technical Fisheries \\ University, 690087 Vladivostok, Russia \\ ${ }^{3}$ Chair of Biodiversity and Marine Bioresources, Far Eastern Federal University, \\ 690090 Vladivostok, Russia
}

\begin{abstract}
*Corresponding author; sturcoal@ mail.ru; 17, Palchevsky St., Vladivostok 690041, Russia
\end{abstract}
\begin{abstract}
The taxonomy of fish in the northeast Pacific area has been recently revised using molecular genetic methods, including the development of a reference library of DNA fragments for species identification. Such libraries are the basis for the development of non-invasive, highthroughput methods for monitoring biodiversity using environmental DNA (eDNA). In order to validate this approach, we used a water eDNA metabarcoding technique based on $12 S$ rRNA and COI mitochondrial fragments and assessed the composition of the twenty northeast Pacific fish species held in a fish tank at the Primorsky Aquarium (Vladivostok, Russia). Only the $12 \mathrm{~S}$ fragment revealed data on fish-related operational taxonomic units (OTUs). Approximately 68\% of the reads were classified into two species of the genus Oncorhynchus, whose shredded fillet is used for feeding. According to the taxonomic identification for the rest of the reads, 8 out of 20 fish species in the tank (40\%) were identified unambiguously, while two species could not be identified. Ten taxa can be considered conditionally identifiable since they might be concealed behind a conflicting taxonomic identification at the genus or family level. In this case, an improvement of the reference library would provide resolution. We detected contamination, which may be related to both intra-laboratory contaminants occurring during DNA extraction and water intake supplying the fish tank.
\end{abstract}

Keywords: 12S, COI, contamination, non-invasive monitoring, OTU, species identification.

\section{Introduction}

Species diversity of fish and fish-like vertebrates of Russian waters includes more than 1400 species (Parin et al. 2014, Orlov and Tokranov 2019), of which more than 1300 inhabit sea waters. Seas of the northeast Pacific Ocean (Sea of Japan, Sea of Okhotsk and the Bering Sea) are characterized by a significant diversity of fish taxa, the systematics of which have been recently revised with increasing use of molecular genetic approaches (Radchenko 2015, Moreva et al. 2017, 2019, Orlova et al. 2019, Turanov et al. 2019, Balakirev et al. 2020, Radchenko et al. 2020). Unified methods are also used in this area, which aim to create a reference library of DNA fragments for accurate fish identification (Mecklenburg, Møller, \& Steinke, 2011; Turanov et al., 2016; Zhang \& Hanner, 2011). This strategy also provides a foundation for the development of high-throughput non-invasive diversity monitoring methods based on environmental DNA (McGee et al. 2019, Weigand et al. 2019, Schenekar et al. 2020). Environmental DNA (eDNA) uses extracellular DNA molecules that are spread by any organism regenerating its own tissues over time, and can be used to trace that organism through environmental samples (Taberlet et al. 2018). Indeed, DNA from the aquatic environment is widely used to assess taxonomic diversity (Thomsen et al. 2012). It can also be used to approximate fish biomass estimates (Salter et al, 2019; Takahara et al., 2012) and provide information on genetic diversity in terms of haplotype variation (Tsuji et al. 2020). However, this 
50

51

52

53

54

55

56

57

58

59

60

61

62

63

64

65

66

67

68

69

70

71

72

73

74

75

76

77

78

79

80

81

82

83

84

85

86

87

88

89

90

91

92

93

94

95

96

97

98

99

100

101

approach is not particularly popular in Russia, and it applies exclusively to the aquatic biodiversity in the west of the country (Velichko et al. 2014, Kirilchik 2018, Lecaudey et al. 2019, Milyutina et al. 2019, Belevich et al. 2020). In order to validate these methods for noninvasive monitoring, mock community analysis (Braukmann et al. 2019) has been used; with respect to fish, taxonomic diversity in aquarium with known fish composition has been analyzed (Kelly et al. 2014, Morey et al. 2020). This makes it possible to assess potential limitations of the approach and generate the necessary methodological recommendations when analyzing natural samples. The present paper reports the evaluation of the northeastern Pacific marine fish composition in a fish tank in the Primorsky Aquarium using eDNA metabarcoding techniques.

\section{Materials and methods}

Water from a tank (volume $1.68 \mathrm{~m}^{3}$ ) at the Primorsky Aquarium (Russky Island, Vladivostok, Primorsky Krai, Russia) was taken on December 12, 2019. This tank holds representatives of the coast of the Far Eastern sea area (Sea of Japan, Sea of Okhotsk, and the Bering Sea). The water temperature is maintained in the range of 10-13 $\square$ C. Taxonomic information and the number of fishes is provided in the Appendix (Suppl. material 1: Table S1). Fishes in this tank are fed with minced fillet of pink (Oncorhynchus gorbuscha (Walbaum, 1792)) and chum salmons (O. keta (Walbaum, 1792)), greenlings (Hexagrammos sp. Tilesius, 1810), chub mackerel (Scomber japonicus Linnaeus, 1758), squids (Todarodes pacificus (Steenstrup, 1880), Berryteuthis magister (Berry, 1913)), and shrimp (Pandalus latirostris Rathbun, 1902). Three replicate samples of water (about $450 \mathrm{ml}$ each) were collected from the tank with a syringe (150 ml capacity, luer lock type). The entire volume of water in each replicate was pushed through a single syringe filter (diameter: $25 \mathrm{~mm}$, pore size: $0.45 \mu \mathrm{m}$, material: PES). The DNA on the filter was fixed by pushing $1 \mathrm{ml}$ of Longmire's buffer through the filter, and next the inlet and outlet holes were closed with combi-stopper plugs. The fixed filter was then stored at $-20 \square$ C. DNA was extracted from the pre-fixed filter using the M-SorbOOM kit (Sintol, Moscow). The manufacturer's protocol was modified such that the lysis buffer was heated to $65 \square \mathrm{C}$, pushed in the reverse direction of filtration (Kesberg and Schleheck 2013) and poured into a clean test tube. The isolated DNA was stored at $-20 \square \mathrm{C}$. Two mitochondrial fragments - $12 S$ rRNA with a length of 170 bp (Miya et al. 2015) and COI with a length of 320 bp (Geller et al. 2013, Leray et al. 2013, Wangensteen et al. 2018) - were used to retrieve the information on the taxonomic diversity from the eDNA samples. A pair of primers with an individual 6-nucleotide tag (doubly-tagged) developed in ecotag (Boyer et al. 2016) was used to amplify the fragments for each sample. Negative PCR controls for each fragment were also performed by using separate pairs of tagged primers. The PCR for each sample was performed using three replicates. The reaction mixture included $10 \mu \mathrm{l}$ of AmpliTaq Gold 360 Master Mix (Thermofisher), $0.5 \mu \mathrm{l}$ of each of the forward and reverse primers $(10 \mu \mathrm{M}), 0.16 \mu \mathrm{l}$ of bovine serum albumin, $10 \mathrm{ng}$ of DNA and deionized water to the final volume $(20 \mu \mathrm{l})$. The thermal cycling profile for the amplification of the COI fragment included preheating at $95 \square \mathrm{C}$ for 10 minutes, followed by 35 cycles according to the following scheme: $1 \mathrm{~min}$. at $94 \square \mathrm{C}, 1 \mathrm{~min}$. at $45 \square \mathrm{C}$ and $1 \mathrm{~min}$. at $72 \square \mathrm{C}$. The final elongation was at $72 \square \mathrm{C}$ for $5 \mathrm{~min}$. The $12 S \mathrm{rRNA}$ fragment was amplified as follows: preheating at $95 \square \mathrm{C}$ for $3 \mathrm{~min}$., 35 cycles of: $98 \square \mathrm{C}$ for $20 \mathrm{sec}, 60 \square \mathrm{C}$ for $15 \mathrm{sec}$, and $72 \square \mathrm{C}$ for $15 \mathrm{sec}$, and a final elongation step at $72 \square \mathrm{C}$ for $5 \mathrm{~min}$. The amplification results were examined by running the fragments on a $1 \%$ agarose gel followed by exposure in ethidium bromide solution and visualization under ultraviolet light. The amplicons were purified with Cleanup S-Cap (Evrogen, Moscow) and normalized (see (Elbrecht and Steinke 2019)) before pooling. The amount of control reactions was taken as the average from the resulting volume of the normalized samples before pooling. Next, the normalized amplicons were combined with the PCR controls and sequenced at Novogene. The library was generated using NEBNext Ultra II DNA Library Prep Kit for Illumina (New England Biolabs, England) and sequenced with an Illumina high-throughput sequencer using a 250 bp paired-end sequencing strategy. 
The obtained reads were processed according to the Begum metabarcoding pipeline (Zepeda-Mendoza et al. 2016, Yang et al. 2020). After adapter removal and preliminary evaluation of the read quality with fastqc, possible read errors were corrected in Spades (Bankevich et al. 2012). Next, paired reads were merged into consensus sequences using PandaSeq (Masella et al. 2012). We then used Begum to demultiplex and filter the reads for each sample. Clustering was done by sumaclust (Mercier et al. 2013) with parameters -t 0.98 and $-\mathrm{R}$ 0.85 . The taxonomic assignment for the generated operational taxonomic units (OTUs) was performed using BLAST (Camacho et al. 2009) implemented in Ubuntu command line interface. The taxonomic information was then summarized in a single table based on the output from the MEGAN community edition program (Huson et al. 2016). The top percent of LCA parameters was set to 2.0 implementing the naïve LCA algorithm with 80 percent to cover. The number of OTUs after taxonomic referencing was corrected using the lulu package (Frøslev et al. 2017) with the following parameters: minimum match $-95 \%$, minimum relative cooccurrence -0.97 .

\section{Results and discussion}

After demultiplexing, the $12 S$ rRNA fragment had 42260 reads, 2827 of which were unique. The $C O I$ fragment accounted for 591 sequences, of which 241 were unique. The controls identified 60 reads for the $12 \mathrm{~S}$ fragment and no reads for COI. After filtering the reads and deleting the chimeric sequences, there were 38441 sequences for $12 S r R N A$ and 289 sequences for COI. The clustering of COI sequences revealed 13 OTUs (Suppl. material 2: Table S2). Most of the reads (289) with six OTUs were not identified (not classified to any of the life domains). Two OTUs with 12 reads in total were assigned to the species Pedobacter ginsengisoli and Polaribacter sp. The remaining five OTUs were classified as eukaryotes, four of which belonged to different multicellular organisms from Annelida (Polydora sp.), Arthropoda (family Miraciidae) and Cnidaria (genus Clytia); one OTU belonged to Phytophthora pseudosyringae from the clade SAR.

Sequences of $12 S$ rRNA clustered into 59 OTUs, four of which were assigned to bacteria with 57 reads in total. The remaining 55 OTUs were related to ray-finned fishes, classified into seven orders, 15 families and 28 genera (Fig. 1). Species-level taxonomy was unambiguously assigned to 23 OTUs (39\%). There were 15 OTUs (25\%) with taxonomic contradictions at the species level; at the genus level, there were nine OTUs (15\%), and one OTU at the family level. The conflict in this case is defined as equal (or undetectable) probability of assigning the same OTU to different taxa according to BLAST. This may indicate either erroneous taxonomic identification of one or several sequences that make up the reference library, or that the marker is highly conserved hence divergence is not sufficient enough to distinguish two or more species. These and other limitations of the approach have been mentioned earlier when estimating fish diversity (Collins et al. 2019, Weigand et al. 2019, Schenekar et al. 2020, Stoeckle et al. 2020). On the other hand, despite the data correction with the lulu R package, some species names were simultaneously assigned to two (Hypsagonus jordani, Ulcina olrikii) and even three (Hypomesus nipponensis, Oncorhynchus keta, Opisthocentrus ocellatus) OTUs (see Suppl. material 3: Table S3). Selecting a standard delineation threshold for clustering based on hierarchical approaches can distort the true number of OTUs. Arguably, more accurate results can be expected from clustering approaches that are based on the natural organization of data without setting a hard cut-off threshold (Hao et al. 2011).

The largest number of reads came from two species of the genus Oncorhynchus (whose fillets are used for feeding, see above) - more than 13000 for each species. Hence, it is encouraged to account for this when planning sufficient sequencing depth for mesocosm experiments (Kelly et al. 2014, Morey et al. 2020) to provide adequate coverage for the detection of DNA for targeted organisms with low amounts of eDNA. An option would be to use blocking primers for the forage organisms, similar to those used in diet assessment. However, it is necessary to consider all the advantages and limitations of this approach (Piñol et al., 2015). Primer bias should not be excluded either (Clarke et al. 2014, Deiner et al. 2017), although its 
impact in this case seems to be less likely. More than 1000 reads were accounted for each of the clusters among Hypomesus nipponensis McAllister, 1963, Hypsagonus jordani Jordan \& Starks, 1904 and Stichaeidae sp. - 26 OTUs had 20 to 1200 reads, whereas each of the other 23 OTUs had less than 20 reads.

We unambiguously identified eight out of 20 taxa (40\%) in the tank. Two taxa present (Alcichthys elongatus (Steindachner 1881), Bero elegans (Steindachner, 1881)) have not been identified, i.e. there is no OTU that might be related to these species. Another 10 taxa $(50 \%)$ may somehow be concealed behind OTUs with conflicting taxonomic reference (see above), such as Chirolophis sp., Lumpenus sp., Pungitius sp., Pleuronectidae sp. (Fig. 1, Suppl. material 3: Table S3). The indication of all these taxa except for Aspidophoroides Lacepède, 1801 and Boreogadus Günther, 1862 in the aquarium may come from environmental DNA originating from the water storage reservoir, whose intake is located next to the Primorsky Aquarium building. Hence, these OTUs may be the result of contamination during DNA isolation or at the PCR stage. The potential for this type of contamination, as well as the presence of hidden sources of environmental DNA, is expected and, regretfully, is not unusual (Kelly et al. 2014, Morey et al. 2020). In addition to reducing the probability of contamination, the development and verification of a reference library for fish identification should be considered as an important way to reduce uncertainty and improve the reliability of high-throughput monitoring methods based on aquatic eDNA (Collins et al. 2019, Weigand et al. 2019).

This preliminary study demonstrates the possible methodological bias of high-throughput DNA-based monitoring from the aquatic environment, and will serve as a starting point for the efficient planning of surveys employing non-invasive methods to monitor aquatic biological diversity of fish in the Russian Far East.

\section{Acknowledgements}

This research was partially supported by a Grant of the President of the Russian Federation (MK-305.2019.4) and Ministry of Science and Higher Education of the Russian Federation (agreement number 075-15-2020-796, grant number 13.1902.21.0012).

\section{Conflict of interest}

Authors declare that they have no conflict of interest.

\section{References}

Balakirev ES, Kravchenko AY, Semenchenko AA (2020) Genetic evidence for a mixed composition of the genus myoxocephalus (Cottoidei: Cottidae) necessitates generic realignment. Genes 11(9): 2-15. https://doi.org/10.3390/genes11091071

Bankevich A, Nurk S, Antipov D, Gurevich AA, Dvorkin M, Kulikov AS, Lesin VM, Nikolenko SI, Pham S, Prjibelski AD, Pyshkin AV., Sirotkin AV., Vyahhi N, Tesler G, Alekseyev MA, Pevzner PA (2012) SPAdes: A new genome assembly algorithm and its applications to single-cell sequencing. Journal of Computational Biology 19(5): 455-477. https://doi.org/10.1089/cmb.2012.0021

Belevich TA, Ilyash LV., Milyutina IA, Logacheva MD, Troitsky AV. (2020) Photosynthetic Picoeukaryotes Diversity in the Underlying Ice Waters of the White Sea, Russia. Diversity 12(3): 93. https://doi.org/10.3390/d12030093

Boyer F, Mercier C, Bonin A, Le Bras Y, Taberlet P, Coissac E (2016) obitools: A unix-inspired software package for DNA metabarcoding. Molecular Ecology Resources 16(1): 176-182. https://doi.org/10.1111/1755-0998.12428

Braukmann TWA, Ivanova NV., Prosser SWJ, Elbrecht V, Steinke D, Ratnasingham S, de Waard JR, Sones JE, Zakharov EV., Hebert PDN (2019) Metabarcoding a diverse arthropod mock community. Molecular Ecology Resources 19(3): 711-727. https://doi.org/10.1111/1755-0998.13008

Camacho C, Coulouris G, Avagyan V, Ma N, Papadopoulos J, Bealer K, Madden TL (2009) 
206

207

208

209

210

211

212

213

214

215

216

217

218

219

220

221

222

223

224

225

226

227

228

229

230

231

232

233

234

235

236

237

238

239

240

241

242

243

244

245

246

247

248

249

250

251

252

253

254

255

256

257

BLAST+: architecture and applications. BMC Bioinformatics 10(1): 421. https://doi.org/10.1186/1471-2105-10-421

Clarke LJ, Soubrier J, Weyrich LS, Cooper A (2014) Environmental metabarcodes for insects: In silico PCR reveals potential for taxonomic bias. Molecular Ecology Resources 14(6): 11601170. https://doi.org/10.1111/1755-0998.12265

Collins RA, Bakker J, Wangensteen OS, Soto AZ, Corrigan L, Sims DW, Genner MJ, Mariani S (2019) Non-specific amplification compromises environmental DNA metabarcoding with COI. Methods in Ecology and Evolution 10(11): 1985-2001. https://doi.org/10.1111/2041210X.13276

Deiner K, Bik HM, Mächler E, Seymour M, Lacoursière $\square$ Roussel A, Altermatt F, Creer S, Bista I, Lodge DM, De Vere N (2017) Environmental DNA metabarcoding: Transforming how we survey animal and plant communities. Molecular Ecology 26(21): 5872-5895. https://doi.org/10.1111/mec. 14350

Elbrecht V, Steinke D (2019) Scaling up DNA metabarcoding for freshwater macrozoobenthos monitoring. Freshwater Biology 64(2): 380-387. https://doi.org/10.1111/fwb.13220

Frøslev TG, Kjøller R, Bruun HH, Ejrnæs R, Brunbjerg AK, Pietroni C, Hansen AJ (2017) Algorithm for post-clustering curation of DNA amplicon data yields reliable biodiversity estimates. Nature Communications 8(1): 1-11. https://doi.org/10.1038/s41467-017-01312-x

Geller J, Meyer C, Parker M, Hawk H (2013) Redesign of PCR primers for mitochondrial cytochrome $\mathrm{c}$ oxidase subunit I for marine invertebrates and application in all-taxa biotic surveys. Molecular Ecology Resources 13(5): 851-861. https://doi.org/10.1111/17550998.12138

Hao X, Jiang R, Chen T (2011) Clustering 16S rRNA for OTU prediction: A method of unsupervised Bayesian clustering. Bioinformatics 27(5): 611-618. https://doi.org/10.1093/bioinformatics/btq725

Huson DH, Beier S, Flade I, Górska A, El-Hadidi M, Mitra S, Ruscheweyh HJ, Tappu R (2016) MEGAN Community Edition - Interactive Exploration and Analysis of Large-Scale Microbiome Sequencing Data. PLoS Computational Biology 12(6): e1004957. https://doi.org/10.1371/journal.pcbi.1004957

Kelly RP, Port JA, Yamahara KM, Crowder LB (2014) Using environmental DNA to census marine fishes in a large mesocosm. PLoS ONE 9(1): e86175. https://doi.org/10.1371/journal.pone.0086175

Kesberg AI, Schleheck D (2013) Improved protocol for recovery of bacterial DNA from water filters: Sonication and backflushing of commercial syringe filters. Journal of Microbiological Methods 93(1): 55-57. https://doi.org/10.1016/j.mimet.2013.02.001

Kirilchik SV (2018) Environmental DNA as a new tool for assessing the biodiversity of Lake Baikal. Limnology and Freshwater Biology 1: 71-73. https://doi.org/10.31951/2658-35182018-A-1-71

Lecaudey LA, Schletterer M, Kuzovlev VV, Hahn C, Weiss SJ (2019) Fish diversity assessment in the headwaters of the Volga River using environmental DNA metabarcoding. Aquatic Conservation: Marine and Freshwater Ecosystems 29(10): 1785-1800. https://doi.org/10.1002/aqc.3163

Leray M, Yang JY, Meyer CP, Mills SC, Agudelo N, Ranwez V, Boehm JT, Machida RJ (2013) A new versatile primer set targeting a short fragment of the mitochondrial COI region for metabarcoding metazoan diversity: Application for characterizing coral reef fish gut contents. Frontiers in Zoology 10(1): 34. https://doi.org/10.1186/1742-9994-10-34

Masella AP, Bartram AK, Truszkowski JM, Brown DG, Neufeld JD (2012) PANDAseq: Pairedend assembler for illumina sequences. BMC Bioinformatics 13(1): 31. https://doi.org/10.1186/1471-2105-13-31

McGee KM, Robinson CV., Hajibabaei M (2019) Gaps in DNA-Based Biomonitoring Across the Globe. Frontiers in Ecology and Evolution 7: 337. https://doi.org/10.3389/fevo.2019.00337 
258

259

260

261

262

263

264

265

266

267

268

269

270

271

272

273

274

275

276

277

278

279

280

281

282

283

284

285

286

287

288

289

290

291

292

293

294

295

296

297

298

299

300

301

302

303

304

305

306

307

308

309

Mecklenburg CW, Møller PR, Steinke D (2011) Biodiversity of arctic marine fishes: taxonomy and zoogeography. Marine Biodiversity 41(1): 109-140. https://doi.org/10.1007/s12526010-0070-z

Mercier C, Boyer F, Bonin A, Coissac E (2013) Programs and Abstracts of the SeqBio 2013 workshop. Abstract SUMATRA and SUMACLUST: fast and exact comparison and clustering of sequences. Programs and Abstracts of the SeqBio 2013 workshop. Abstract, 27-29.

Milyutina IA, Belevich TA, Ilyash LV., Troitsky AV. (2019) Insight into picophytoplankton diversity of the subarctic White Sea-The first recording of Pedinophyceae in environmental DNA. MicrobiologyOpen 8(10): e892. https://doi.org/10.1002/mbo3.892

Miya M, Sato Y, Fukunaga T, Sado T, Poulsen JY, Sato K, Minamoto T, Yamamoto S, Yamanaka H, Araki H, Kondoh M, Iwasaki W (2015) MiFish, a set of universal PCR primers for metabarcoding environmental DNA from fishes: Detection of more than 230 subtropical marine species. Royal Society Open Science 2(7): 150088. https://doi.org/10.1098/rsos.150088

Moreva I, Radchenko O, Petrovskaya A, Borisenko S (2017) Molecular genetic and karyological analysis of antlered sculpins of Enophrys diceraus group (Cottidae). Russian Journal of Genetics 53(97): 1030-1041. https://doi.org/10.1134/S1022795417090113

Moreva IN, Radchenko OA, Petrovskaya AV (2019) Karyological and Molecular Genetic Differentiation of Fringed Sculpins of the Genus Porocottus Gill, 1859 (Cottidae: Myoxocephalinae). Russian Journal of Marine Biology 45(2): 128-136. https://doi.org/10.1134/S1063074019020081

Morey KC, Bartley TJ, Hanner RH (2020) Validating environmental DNA metabarcoding for marine fishes in diverse ecosystems using a public aquarium. Environmental DNA 2: 330342. https://doi.org/10.1002/edn3.76

Orlov AM, Tokranov AM (2019) Checklist of deep-sea fishes of the Russian northwestern Pacific Ocean found at depths below 1000 $\square \mathrm{m}$. Progress in Oceanography 176: 102143. https://doi.org/10.1016/j.pocean.2019.102143

Orlova SY, Volkov AA, Shcepetov DM, Maznikova OA, Chernova NV., Chikurova EA, Glebov II, Orlov AM (2019) Inter- and Intra-Species Relationships of Greenland Halibut Reinhardtius hippoglossoides (Pleuronectidae) Based on the Analysis of Nuclear and Mitochondrial Genetic Markers. Journal of Ichthyology 59(1): 65-77. https://doi.org/10.1134/S0032945219010119

Parin NV, Evseenko SA, Vasil'eva ED (2014) Fishes of the Rusian Seas: Annotated Catalogue. KMK Scientific Press, Moscow, 733 pp.

Piñol J, Mir G, Gomez-Polo P, Agustí N (2015) Universal and blocking primer mismatches limit the use of high-throughput DNA sequencing for the quantitative metabarcoding of arthropods. Molecular Ecology Resources 15(4): 819-830. https://doi.org/10.1111/17550998.12355

Radchenko OA (2015) The system of the suborder Zoarcoidei (Pisces, Perciformes) as inferred from molecular genetic data. Russian Journal of Genetics 51(11): 1096-1112. https://doi.org/10.1134/S1022795415100130

Radchenko OA, Moreva IN, Petrovskaya AV. (2020) Karyological and Molecular Genetic Divergence of Sculpins Myoxocephalus Gill, 1859 (Cottidae). Russian Journal of Genetics 56(10): 1212-1223. https://doi.org/10.1134/S1022795420100117

Salter I, Joensen M, Kristiansen R, Steingrund P, Vestergaard P (2019) Environmental DNA concentrations are correlated with regional biomass of Atlantic cod in oceanic waters. Communications Biology 2(1): 1-9. https://doi.org/10.1038/s42003-019-0696-8

Schenekar T, Schletterer M, Lecaudey LA, Weiss SJ (2020) Reference databases, primer choice, and assay sensitivity for environmental metabarcoding: Lessons learnt from a re-evaluation of an eDNA fish assessment in the Volga headwaters. River Research and Applications 36(7): 1004-1013. https://doi.org/10.1002/rra.3610 
310

Stoeckle MY, Das Mishu M, Charlop-Powers Z (2020) Improved Environmental DNA Reference Library Detects Overlooked Marine Fishes in New Jersey, United States. Frontiers in Marine Science 7: 226. https://doi.org/10.3389/fmars.2020.00226

Taberlet P, Bonin A, Zinger L, Coissac E (2018) Environmental DNA: For Biodiversity Research and Monitoring Environmental DNA: For biodiversity research and monitoring. Oxford University Press. https://doi.org/10.1093/oso/9780198767220.001.0001

Takahara T, Minamoto T, Yamanaka H, Doi H, Kawabata Z (2012) Estimation of fish biomass $\begin{array}{llllll}\text { using environmental DNA. PLoS ONE } & \text { 7(4): } & \text { e35868 }\end{array}$ https://doi.org/10.1371/journal.pone.0035868

Thomsen PF, Kielgast J, Iversen LL, Møller PR, Rasmussen M, Willerslev E (2012) Detection of a Diverse Marine Fish Fauna Using Environmental DNA from Seawater Samples. PLoS ONE 7(8): e41732. https://doi.org/10.1371/journal.pone.0041732

Tsuji S, Shibata N, Sawada H, Ushio M (2020) Quantitative evaluation of intraspecific genetic diversity in a natural fish population using environmental DNA analysis. Molecular Ecology Resources 20: 1323-1332. https://doi.org/10.1111/1755-0998.13200

Turanov SV., Balanov AA, Shelekhov VA (2019) Species of the genus Ammodytes (Ammodytidae) in the northwestern part of the Sea of Japan. Journal of Applied Ichthyology 35(6): 1303-1306. https://doi.org/10.1111/jai.13981

Turanov SV, Kartavtsev YP, Lipinsky VV, Zemnukhov VV, Balanov AA, Lee Y-H, Jeong D (2016) DNA-barcoding of perch-like fishes (Actinopterygii: Perciformes) from far-eastern seas of Russia with taxonomic remarks for some groups. Mitochondrial DNA 27(2): 11881209. https://doi.org/10.3109/19401736.2014.945525

Velichko N, Averina S, Gavrilova O, Ivanikova N, Pinevich AV. (2014) Probing environmental DNA reveals circum-Baltic presence and diversity of chlorophyll a/b-containing filamentous cyanobacteria (genus Prochlorothrix). Hydrobiologia 736(1): 165-177. https://doi.org/10.1007/s10750-014-1903-8

Wangensteen OS, Palacín C, Guardiola M, Turon X (2018) DNA metabarcoding of littoral hardbottom communities: High diversity and database gaps revealed by two molecular markers. PeerJ 6: e4705. https://doi.org/10.7717/peerj.4705

Weigand H, Beermann AJ, Čiampor F, Costa FO, Csabai Z, Duarte S, Geiger MF, Grabowski M, Rimet F, Rulik B, Strand M, Szucsich N, Weigand AM, Willassen E, Wyler SA, Bouchez A, Borja A, Čiamporová-Zatovičová Z, Ferreira S, Dijkstra KDB, Eisendle U, Freyhof J, Gadawski P, Graf W, Haegerbaeumer A, van der Hoorn BB, Japoshvili B, Keresztes L, Keskin E, Leese F, Macher JN, Mamos T, Paz G, Pešić V, Pfannkuchen DM, Pfannkuchen MA, Price BW, Rinkevich B, Teixeira MAL, Várbíró G, Ekrem T (2019) DNA barcode reference libraries for the monitoring of aquatic biota in Europe: Gap-analysis and recommendations for future work. Science of the Total Environment 678: 499-524. https://doi.org/10.1016/j.scitotenv.2019.04.247

Yang CW, Bohmann K, Wang X, Cai W, Wales N, Ding Z, Gopalakrishnan S, Douglas WY (2020) Biodiversity Soup II: A bulk-sample metabarcoding pipeline emphasizing error reduction. bioRxiv. https://doi.org/10.1101/2020.07.07.187666

Zepeda-Mendoza ML, Bohmann K, Carmona Baez A, Gilbert MTP (2016) DAMe: A toolkit for the initial processing of datasets with PCR replicates of double-tagged amplicons for DNA metabarcoding analyses. BMC Research Notes 9(1): 1-13. https://doi.org/10.1186/s13104016-2064-9

Zhang J-B, Hanner R (2011) DNA barcoding is a useful tool for the identification of marine fishes from Japan. Biochemical Systematics and Ecology 39(1): 31-42. https://doi.org/10.1016/j.bse.2010.12.017 
bioRxiv preprint doi: https://doi.org/10.1101/2020.12.21.423745; this version posted December 22, 2020. The copyright holder for this preprint (which was not certified by peer review) is the author/funder, who has granted bioRxiv a license to display the preprint in perpetuity. It is made available under aCC-BY-NC 4.0 International license.

\section{Figures}

Acanthogobius lactipes

Agonidae sp.

Argyrocottus zanderi

Artediellus sp.

Bathymaster derjugini

Blepsias cirrhosus

Boreogadus saida

Chirolophis sp.

Engraulis japonicus

Ernogrammus hexagrammus

Gymnelus hemifasciatus

Gymnocanthus sp.

Gymnocanthus tricuspis

Gymnogobius heptacanthus

Hemilepidotus sp.

Hypomesus nipponensis

Hypoptychus dybowskii

Hypsagonus jordani

Liparis sp. 1-2

Lumpenus sp.

Lycodes tanakae

Myoxocephalus sp. 1-3

Oncorhynchus keta

Oncorhynchus sp.

Opisthocentrus ocellatus

Perciformes sp.

Pholis sp. 1-2

Pleuronectidae sp. 1-2

Porocottus allisi

Pungitius sp.

Rhodymenichthys dolichogaster

Stichaeidae sp. 1-5

Stichaeus punctatus

Triglops pingelii

Ulcina olrikii

Zoarcidae sp.

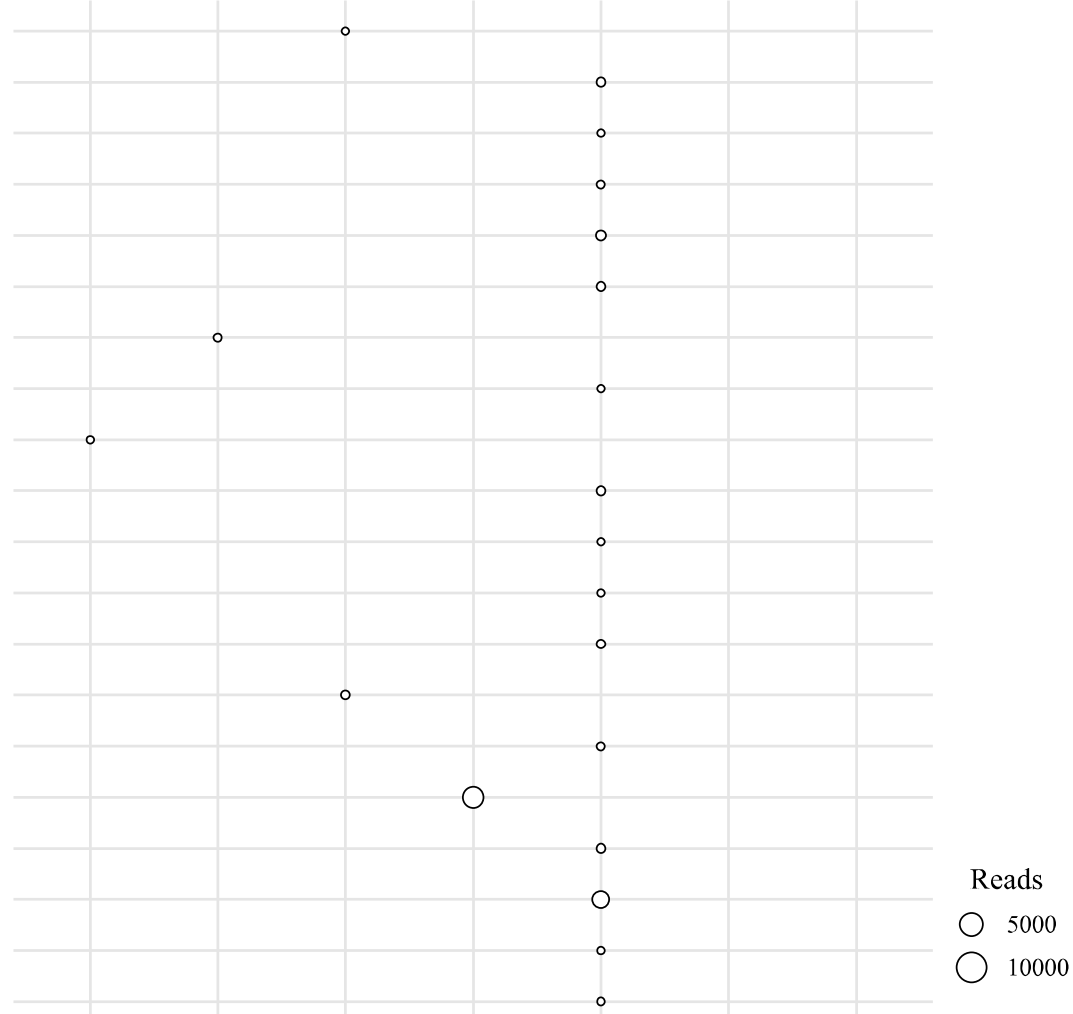

Figure 1. A bubble graph showing the number of reads for different OTUs obtained for $12 S$ rRNA, amplified based on the water eDNA samples from a fish tank at the Primorsky 
370 Aquarium. The orders are presented horizontally and the OTUs are placed vertically. The size of 371 circles demonstrates the number of reads assigned to the different OTUs. OTU names in bold

\section{Appendices}

Supplementary material 1, Table S1. Fish species composition in the tank of the Primorsky Aquarium where marine aquatic eDNA was collected from. Unambiguously identified taxa are highlighted by blue color. Species that were not identified are highlighted by red color.

Supplementary material 2, Table S2. Assigned OTUs for COI marker.

Supplementary material 3, Table S3. Assigned OTUs for 12 rRNA marker. 